\title{
Dyskurs na temat obowiązkowych szczepień ochronnych w opinii rodziców
}

\section{Discourse on compulsory vaccinations}

\author{
Artur Kotwasㄹ, Natalia Czerniak², Paulina Zabielska ${ }^{1 凶}$, Beata Karakiewicz $^{1}$ \\ 1 Pomorski Uniwersytet Medyczny w Szczecinie, Katedra i Zakład Zdrowia Publicznego, ul. Żołnierska 48, 71-210 Szczecin \\ 2 Pomorski Uniwersytet Medyczny w Szczecinie, Studenckie Koło Naukowe przy Katedrze i Zakładzie Zdrowia Publicznego, ul. Żołnierska 48, 71-210 Szczecin \\ $\triangle$ paulina.zabielska@pum.edu.pl
}

\begin{abstract}
Introduction: Vaccinations are an extremely effective way to fight against infectious diseases, which is why many countries have adopted a compulsory vaccination policy following the recommendations of epidemiological institutes. As with any technology, this approach has found a wide range of supporters, but also a group of critics who deny the effectiveness of vaccination.

The research concerned the opinions of parents regarding compulsory paediatric immunization.

Materials and methods: The study group consisted of 200 parents at the age of 26-60 years. The results were analysed with statistical methods using PASW Statistics v.18.

Results: Immunization in children was opposed by 30 (15\%) people, including $22(22 \%)$ from Lubuskie province and $8(8 \%)$ from the West Pomeranian province in Poland, 18 (13\%) women
\end{abstract}

and $12(19.4 \%)$ men. The vast majority of respondents (270 people; $85 \%$ ) expressed approval for immunization. The opinions of representatives of the medical professions (physicians, nurses) were usually very important or important for the parents - a total of $145(72.5 \%)$ people. Overall, $49(24.5 \%)$ patients agreed with the opinions of the anti-vaccination movement.

Conclusions: The study shows that despite the existence of the anti-vaccination movement, the public continues to approve of compulsory vaccination, and considers it an important element of prevention against serious diseases. Despite this, parents feel that they have limited access to information, which prevents them from reaching fully informed decisions about the vaccination of children.

Keywords: compulsory vaccination; school-age children; parent's opinion; the anti-vaccination movement; vaccinology; voluntary vaccination.

\begin{abstract}
ABSTRAKT
Wstęp: Szczepienia są niezwykle skutecznym sposobem walki z chorobami zakaźnymi, dlatego w wielu państwach są obowiązkowe zgodnie z zaleceniami instytutów epidemiologicznych. Jak każda technologia, także i ta oprócz dużego grona zwolenników znalazła grupę krytyków, którzy negują skuteczność szczepień. Głównym celem badania było poznanie opinii rodziców na temat obowiązkowych szczepień ochronnych wieku dziecięcego.

Materiały i metody: Grupę badaną stanowiło 200 rodziców w wieku 26-6o lat. Uzyskane wyniki poddano analizie statystycznej w programie PASW Statistics V.18.

Wyniki: Brak poparcia dla szczepień ochronnych wieku dziecięcego wyraziło 30 (15\%) osób, wśród których było 18 (13\%) kobiet i $12(19,4 \%)$ mężczyzn; 22 (22\%) osoby były z woj. lubuskiego,
\end{abstract}

8 (8\%) z woj. zachodniopomorskiego. Zdecydowana większość respondentów (270 osób; 85\%) popierała obowiązkowe szczepienia ochronne. Bardzo ważne i ważne dla rodziców (145osób, $72,5 \%$ ) były najczęściej opinie reprezentantów zawodów medycznych (lekarz, pielęgniarka). Z poglądami ruchu antyszczepionkowego zgadzało się 49 (24,5\%) osób.

Wnioski: Pomimo poparcia dla ruchu antyszczepionkowego większość społeczeństwa uznaje obowiązek szczepień za ważny element profilaktyki poważnych chorób. Rodzice uważają jednak, że mają ograniczony dostęp do informacji, co uniemożliwia im w pełni świadome podjęcie decyzji o zaszczepieniu dzieci. Słowa kluczowe: obowiązkowe szczepienia ochronne; dzieci w wieku szkolnym; opinia rodziców; ruch antyszczepionkowy; wakcynologia; dobrowolne szczepienia.

\section{WSTĘP}

Choroby zakaźne od zawsze stanowiły duże zagrożenie epidemiologiczne. Pomimo znacznego wzrostu świadomości oraz poprawy warunków bytowych i higieny choroby te ciągle występują. Już w XVIII w. zaczęto poszukiwać medycznych rozwiązań, które zwiększyłyby odporność społeczeństwa. W 1796 r. wynaleziono pierwszą szczepionkę, która miała zapobiegać zachorowaniu na ospę prawdziwą, stanowiącą

poważny problem w XVIII-wiecznej Europie. Od tamtej pory rozwój wakcynologii znacznie przyśpieszył [1].

Szczepienia okazały się także niezwykle skutecznym sposobem walki z chorobami zakaźnymi, dlatego w wielu państwach wprowadzono obowiązek szczepień zgodnie z zaleceniami instytutów epidemiologicznych [2].

W Polsce szczepienia ochronne są realizowane zgodnie z obowiązującym programem szczepień ochronnych, który jest co roku aktualizowany. Dokument ten uwzględnia szczepienia 
bezpłatne (tzw. obowiązkowe) oraz szczepienia odpłatne (tzw. zalecane) [3].

Szczepionki to preparaty zawierające w swoim składzie antygeny bakteryjne lub wirusowe i substancje pomocnicze oraz stabilizujące. Antygeny wywołują odpowiedź immunologiczną przeciw danemu drobnoustrojowi. Są nimi drobnoustroje żywe atenuowane (tj. pozbawione zjadliwości, np. w przypadku gruźlicy) lub martwe inaktywowane bądź ich fragmenty. Szczepionki produkowane są jako preparaty monowalentne, poliwalentne lub skojarzone [4].

Jak każda technologia, także i ta oprócz szerokiego grona zwolenników znalazła grupę krytyków, którzy negują skuteczność szczepień [5]. Powstał ruch antyszczepionkowy prezentujący ciągle niepotwierdzone teorie głoszące, że szczepienia wywołują choroby i są poważnym zagrożeniem dla prawidłowego rozwoju dziecka. Zwolennicy ruchu uzasadniają swoje opinie, tłumacząc, że szczepionki zawierają rtęć, aluminium i formaldehyd [6]. Przeciwnicy szczepień oprócz autyzmu obawiają się również wystąpienia innych powikłań [7].

Faktem jest, że tak jak każdy zabieg medyczny szczepienia mogą mieć działania niepożądane, do których zalicza się ostre alergie na poszczególne składniki szczepionek oraz chorobę poszczepienną (osłabienie i gorączka wynikające z podania do organizmu dawki atenuowanych drobnoustrojów) [8]. Również zawarte w szczepionkach aluminium może mieć realny wpływ na funkcjonowanie układu nerwowego [9].

Na podstawie badań potwierdzono wystąpienie jedynie takich powikłań poszczepiennych jak gorączki i drgawki gorączkowe po podaniu szczepienia oraz różnego rodzaju odczyny alergiczne. Pomimo że prawdą jest, iż substancje dodatkowe zawarte w szczepionkach mogą mieć negatywny wpływ na układ neurologiczny ludzkiego organizmu, to jednak stężenie tych substancji w szczepionkach jest bardzo niewielkie, co minimalizuje skutki ich działania [10]. W Polsce istotne odczyny poszczepienne zdarzają się niezwykle rzadko. Działanie szczepionki bardzo często nakłada się na objawy choroby, dlatego trudno jest ustalić dokładną częstość odczynów niepożądanych [11].

Do zwolenników szczepień należy Światowa Organizacja Zdrowia, której specjaliści są autorytetami w dziedzinach medycyny, epidemiologii i zdrowia publicznego. Obecny stan wiedzy pozwala na udowodnienie przede wszystkim pozytywnych skutków szczepień, które są dużo istotniejsze społecznie niż potencjalne skutki uboczne, stąd zaleca się w dalszym ciągu powszechny system szczepień. Część państw nie chcąc odbierać decyzyjności rodziców wobec dzieci, świadomie odstąpiła od obowiązku szczepień i jedynie prowadzi programy informacyjne zachęcające do szczepienia [10].

Różnorodność opinii prezentowanych przez rodziców oraz inne osoby zachęciła wielu badaczy do prowadzenia licznych badań oceniających poglądy, a także przyczyny nastawienia respondentów do szczepień ochronnych.

Głównym celem pracy było poznanie opinii rodziców na temat obowiązkowych szczepień ochronnych (OSO) wieku dziecięcego. Obrano także cele szczegółowe, wśród których znalazło się poznanie poglądów na temat ruchu antyszczepionkowego i różnic w odpowiedziach udzielanych przez respondentów.

\section{MATERIAŁY I METODY}

Badania przeprowadzono w 2016 r. w wybranych losowo szkołach województw lubuskiego i zachodniopomorskiego. Anonimowa autorska ankieta została przeprowadzona podczas zebrania z rodzicami, którzy zostali poinformowani o celu badania oraz wyrazili świadomą i dobrowolną zgodę na udział. Po weryfikacji kompletności do badania włączono 200 kwestionariuszy badawczych (100\%). Uzyskane wyniki poddano analizie statystycznej w programie PASW Statistics v.18. W celu wykrycia ważnych różnic pomiędzy analizowanymi zmiennymi wykorzystano testy: $\chi^{2}$, U Manna-Whitneya oraz H KruskalaWallisa. Jako istotne statystycznie uznano wyniki przy $\mathrm{p}<0,05$.

Kobiety stanowiły 69\% (138 osób) badanych, a mężczyźni 31\% (62 osoby). Rozkład wieku rodziców wynosił 26-60 lat. Średnia arytmetyczna z odchyleniem standardowym wieku kobiet liczyła 38,41 $\pm 5,60$ lat, a mężczyzn 40,48 $\pm 5,37$ lat. Badani reprezentowali województwa w 50\% proporcji. Różnice wieku rodziców z badanych województw nie były istotne $(\mathrm{p}>0,05)$.

\section{WYNIKI}

Zweryfikowano poparcie dla szczepień ochronnych wieku dziecięcego. Zanegowało je 30 (15\%) osób, w tym 22 (22\%) z woj. lubuskiego i 8 (8\%) z woj. zachodniopomorskiego - co stanowiło różnicę statystycznie istotną $(\mathrm{p} \leq 0,05)$. Wśród negujących było 18 (13\%) kobiet i 12 (19,4\%) mężczyzn. Zdecydowana większość respondentów (270 osób; 85\%) wyraziła poparcie dla OSO. Wiek nie różnicował istotnie opinii wobec omawianych szczepień $(\mathrm{p}>0,05)$ - tabela 1 .

W dalszym etapie badano przyczyny braku akceptacji dla obowiązku szczepień. Osoby, które wyraziły brak poparcia dla szczepień ochronnych, poproszono o uzasadnienie takiej opinii. Najczęściej podnoszona była obawa przed wywoływaniem chorób (15 osób; 7,5\%). Zdecydowanie częściej wskazywana była ona przez mieszkańców woj. lubuskiego niż woj. zachodniopomorskiego (14 osób vs 1 osoba). Respondenci niepopierający OSO wskazywali także na ograniczanie naturalnej odporności dziecka (10 osób; 5\%). Ten argument nieco częściej

TABELA 1. Poparcie dla obowiązkowych szczepień ochronnych

\begin{tabular}{lccc|cc|c}
\multirow{2}{*}{ Poparcie } & \multicolumn{4}{c}{ Płeć } & \multicolumn{2}{c}{ Województwo } \\
\cline { 2 - 6 } & & kobieta & mężczyzna & lubuskie & $\begin{array}{c}\text { zachodnio- } \\
\text { pomorskie }\end{array}$ & Ogółem \\
\hline \multirow{2}{*}{ Nie } & $\mathrm{n}$ & 18 & 12 & 22 & 8 & 30 \\
\cline { 2 - 6 } & $\%$ & 13,0 & 19,4 & 22,0 & 8,0 & 15,0 \\
\hline \multirow{2}{*}{ Tak } & $\mathrm{n}$ & 120 & 50 & 78 & 92 & 170 \\
\cline { 2 - 6 } & $\%$ & 87,0 & 80,6 & 78,0 & 92,0 & 85,0 \\
\hline \multirow{2}{*}{ Ogółem } & $\mathrm{n}$ & 138 & 62 & 100 & 100 & 200 \\
\cline { 2 - 6 } & $\%$ & 100,0 & 100,0 & 100,0 & 100,0 & 100,0 \\
\hline$X^{2} ; p$ & & 1,337 & 0,248 & 7,686 & 0,006 & - \\
\hline
\end{tabular}


podawały osoby z woj. zachodniopomorskiego niż z woj. lubuskiego (6 vs 4 osoby).

Wpływ na społeczną opinię ma wiele różnych czynników. Ankietowani oceniali istotność wpływu poszczególnych bodźców na wykształcenie opinii na temat obowiązkowych i dodatkowych szczepień ochronnych wieku dziecięcego. Bardzo ważne i ważne dla rodziców były najczęściej opinie reprezentantów zawodów medycznych (lekarza, pielęgniarki) łącznie 145 (72,5\%) osób. Nieco mniej istotnym bodźcem była opinia rodziny (105 osób; 52,5\%). Media, w tym Internet, znajomi czy ksiądz stanowili zdecydowanie mniej ważne źródła kształtujące opinię.

Nie wszyscy rodzice stosowali się do prawnego obowiązku szczepień. Część osób była również przekonana, że szczepienia nie są obowiązkowe. W związku z tym zbadano odsetek osób nieszczepiących swoich dzieci. Wśród respondentów z woj. lubuskiego nie szczepiło dziecka $9 \%$ badanych, a z woj. zachodniopomorskiego - 3\%. Zastosowany test $\chi_{2}$ nie pokazał zależnego statystycznie wpływu miejsca zamieszkania na decyzję rodziców o szczepieniu dzieci ( $p>0,05)$. Sprawdzono także, czy wiek rodzica istotnie różnicował podejmowanie decyzji o szczepieniu dziecka. Różnice w wartości średniej były niewielkie: szczepili rodzice w wieku 38,93 $\pm 5,47$ lat; nie szczepili $41 \pm 7,36$ lat. Za pomocą testu statystycznego U Manna-Whitneya nie wykazano istotnej statystycznie zależności realizacji szczepień u dzieci od wieku rodziców $(p>0,05)$. Poza informacjami na temat OSO respondenci zostali zapytani także o wykonywanie u swoich dzieci szczepień nieobowiązkowych i opinie na ten temat. Niespełna połowa badanych (92 osoby; $46 \%$ ) potwierdziła wykonywanie tego rodzaju szczepień, a 108 (54\%) osób nie wykonywało żadnego spośród znajdujących się na liście zalecanych szczepień ochronnych. W woj. lubuskim na szczepienia dodatkowe zdecydowało się 40\% ankietowanych, a w zachodniopomorskim - 52\%. Przy zastosowaniu testu $\chi^{2}$ wykazano brak istotnych statystycznie różnic ( $p>0,05)$. Zarówno płeć, jak i wiek rodzica nie miały istotnego wpływu na decyzję o szczepieniach dodatkowych ( $p>0,05)$. Wśród nieobowiązkowych najczęstsze były szczepienia przeciwko pneumokokom (47 osób; 23,5\%) oraz grypie (39 osób; 19,5\%) - rycina 1.

W następnym etapie zbadano, jak istotnie wpłynąłby na decyzję o wykonaniu szczepień brak obowiązku ich wykonania. Zdecydowana większość ankietowanych z obu województw

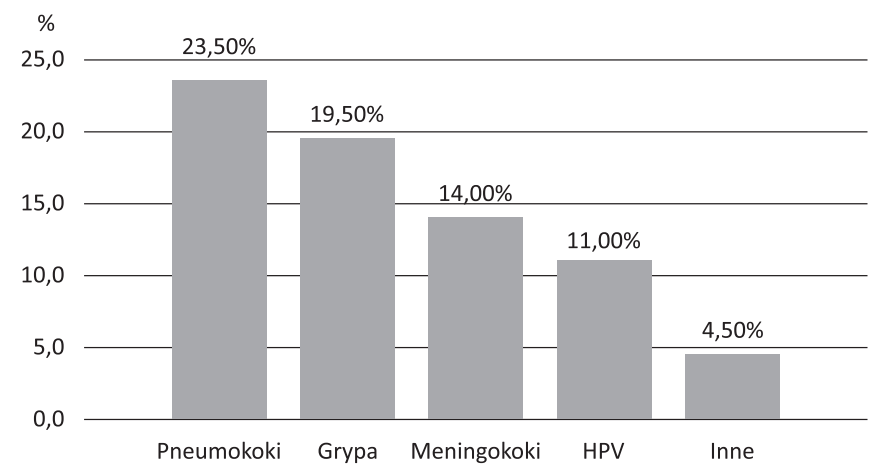

RYCINA 1. Częstość wykonywania szczepień dodatkowych odpowiedziała, że podjęłaby decyzję o zaszczepieniu dziecka (164 osoby; 82\%). W woj. lubuskim w ten sposób odpowiedziało $77 \%$, a w woj. zachodniopomorskim $87 \%$ badanych. Wśród pozostałych $36(18 \%)$ rodziców 1 osoba nie udzieliła odpowiedzi na pytanie, a pozostałe 17 osób wybrało odpowiedź przeczącą. Zastosowany test $\mathrm{H}$ potwierdził istotność różnic odpowiedzi rodziców $(\mathrm{p} \leq 0,05)$ - tabela 2 .

TABELA 2. Skłonność do poddawania dziecka obowiązkowym szczepieniom ochronnym w przypadku ich dobrowolności

\begin{tabular}{lcccc}
\multirow{2}{*}{$\begin{array}{l}\text { Wykonywanie } \\
\text { szczepień }\end{array}$} & \multicolumn{3}{c}{ Województwo } & Ogółem \\
\cline { 2 - 4 } Brak odp. & $\mathrm{n}$ & 0 & $\begin{array}{c}\text { zachodnio- } \\
\text { pomorskie }\end{array}$ & \\
\cline { 2 - 5 } & $\%$ & 0,0 & 1,0 & 1 \\
\hline \multirow{2}{*}{ Tak } & $\mathrm{n}$ & 77 & 87 & 0,5 \\
\hline \multirow{2}{*}{ Nie } & $\%$ & 77,0 & 87,0 & 164 \\
\hline \multirow{2}{*}{ Ogółem } & $\mathrm{n}$ & 23 & 12 & 82,0 \\
\cline { 2 - 5 } & $\%$ & 23,0 & 12,0 & 35 \\
\hline $\mathrm{H} ; \mathrm{p}$ & $\mathrm{n}$ & 100 & 100 & 17,5 \\
\hline
\end{tabular}

Ankietowani ocenili również, czy wg nich szczepienia wieku dziecięcego powinny być obowiązkowe. Zdecydowana mniejszość (32 osoby; 16\%), oceniła, że szczepienia nie powinny być obowiązkowe, przede wszystkim dlatego, że taki obowiązek ogranicza autonomię rodziców w kwestii opieki nad dziećmi (26 osób; 13\%), a poza tym może powodować choroby (21 osób; 10,5\%). Większość badanych (168 osób; 84\%) uważa, że szczepienia powinny być obowiązkowe, ponieważ zapobiegają występowaniu chorób (148 osób; 74,5\%) i stanowią skuteczną profilaktykę (109 osób; 54\%). Odpowiedzi na to pytanie przedstawiono na rycinie 2 .

Następnym etapem badawczym było poznanie opinii na temat ruchu antyszczepionkowego. Świadomość jego istnienia potwierdziło 126 (63\%) osób, w tym 75\% mieszkańców woj. lubuskiego i 51\% woj. zachodniopomorskiego. Różnice pomiędzy województwami były istotne $(\mathrm{p} \leq 0,05)$ - tabela 3 .

Odpowiedzi twierdzącej na to pytanie udzielały osoby starsze. Średnia ich wieku wyniosła 39,83 $\pm 5,32$ lata; u oponentów zaś $37,73 \pm 5,85$. Różnice $w$ wieku były znamienne statystycznie $(\mathrm{p}=0,025)$.

TABELA 3. Świadomość istnienia ruchu antyszczepionkowego

\begin{tabular}{|c|c|c|c|c|c|c|}
\hline \multirow{2}{*}{\multicolumn{2}{|c|}{$\begin{array}{c}\text { Świadomość } \\
\text { istnienia ruchu } \\
\text { antyszczepionkowego }\end{array}$}} & \multicolumn{2}{|c|}{ Płeć } & \multicolumn{2}{|c|}{ Województwo } & \multirow[b]{2}{*}{ Ogótem } \\
\hline & & kobieta & $\begin{array}{c}\text { męż- } \\
\text { czyzna }\end{array}$ & lubuskie & $\begin{array}{l}\text { zachodnio- } \\
\text { pomorskie }\end{array}$ & \\
\hline \multirow{2}{*}{ Nie } & $n$ & 85 & 41 & 75 & 51 & 126 \\
\hline & $\%$ & 61,6 & 66,1 & 75,0 & 51,0 & 63,0 \\
\hline \multirow{2}{*}{ Tak } & $\mathrm{n}$ & 53 & 21 & 25 & 49 & 74 \\
\hline & $\%$ & 38,4 & 33,9 & 25,0 & 49,0 & 37,0 \\
\hline \multirow{2}{*}{ Ogółem } & $n$ & 138 & 62 & 100 & 100 & 200 \\
\hline & $\%$ & 100,0 & 100,0 & 100,0 & 100,0 & 100,0 \\
\hline$x^{2} ; p$ & & 0,377 & 0,539 & 12,355 & 0,000 & - \\
\hline
\end{tabular}




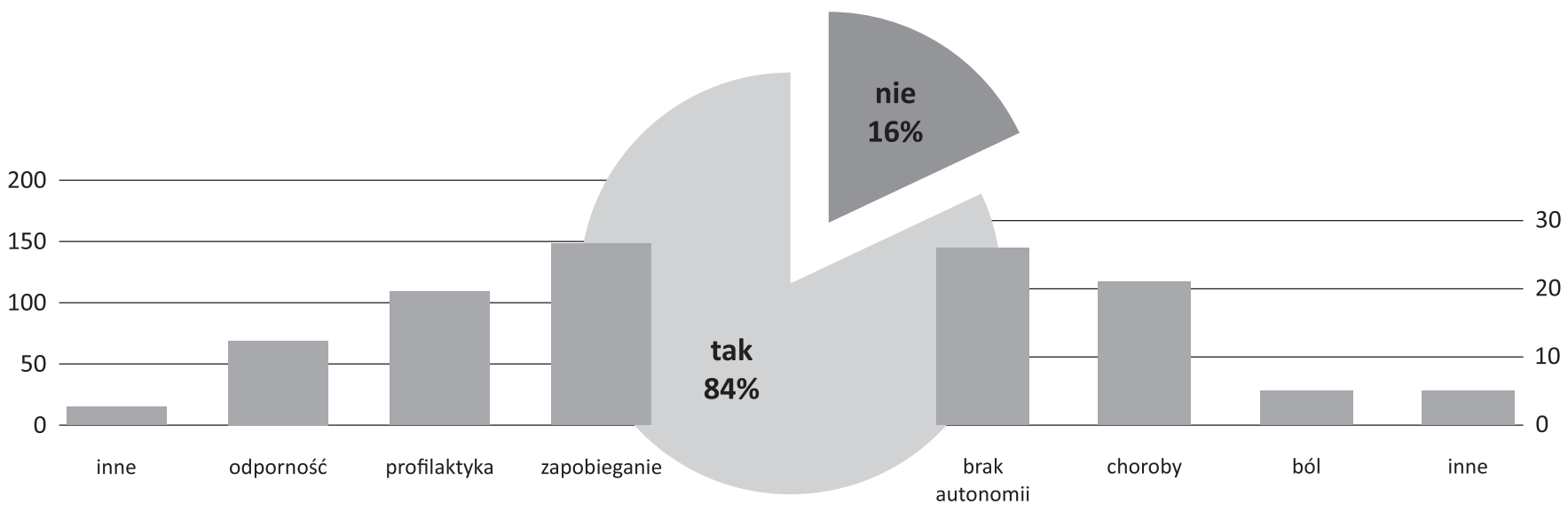

RYCINA 2. Opinia na temat obowiązkowości szczepień i jej uzasadnienie

Po przeczytaniu krótkiej, obiektywnej informacji na temat ruchu antyszczepionkowego ankietowani ocenili, czy zgadzają się z jego założeniami. W ujęciu ogólnym 49 (24,5\%) osób zgadzało się z poglądami ruchu, w tym $30 \%$ badanych z woj. lubuskiego i 19\% z woj. zachodniopomorskiego. Pewne różnice występują także pod względem płci badanych $(27,4 \%$ i $23,2 \%$ mężczyzn popiera postulaty ruchu). Przeprowadzone wnioskowanie statystyczne w obu przypadkach nie potwierdziło istotności różnic $(\mathrm{p}>0,05)$.

TABELA 4. Zależność poparcia dla obowiązkowych szczepień ochronnych od poparcia dla ruchu antyszczepionkowego

\begin{tabular}{|c|c|c|c|c|}
\hline \multirow{2}{*}{\multicolumn{2}{|c|}{$\begin{array}{c}\text { Czy popiera } \\
\text { Pan/Pani obowiązkowe } \\
\text { szczepienia ochronne } \\
\text { wieku dziecięcego? }\end{array}$}} & \multicolumn{2}{|c|}{$\begin{array}{c}\text { Czy zgadza się Pan/Pani } \\
\text { z poglądami prezentowanymi } \\
\text { przez ten ruch? }\end{array}$} & \multirow{3}{*}{$\begin{array}{c}\text { Ogółem } \\
30\end{array}$} \\
\hline & & tak & nie & \\
\hline \multirow{2}{*}{ Nie } & $n$ & 27 & 3 & \\
\hline & $\%$ & 90,0 & 10,0 & 100,0 \\
\hline \multirow{2}{*}{ Tak } & $n$ & 22 & 148 & 170 \\
\hline & $\%$ & 12,9 & 87,1 & 100,0 \\
\hline \multirow{2}{*}{ Ogółem } & $\mathrm{n}$ & 49 & 151 & 200 \\
\hline & $\%$ & 24,5 & 75,5 & 100,0 \\
\hline$x^{2}, p$ & & \multicolumn{3}{|c|}{81,$860 ; 0,000$} \\
\hline
\end{tabular}

Sprawdzono, czy istnieje związek pomiędzy opiniami na temat OSO a tezami ruchu antyszczepionkowego. Wyniki przedstawiono w tabeli 4. Okazało się, że 27 osób (90\%) badanych, którzy nie popierają szczepień, popiera ruch antyszczepionkowy, a 148 (87,1\%) zwolenników szczepień tego ruchu nie popiera. Istotność przedstawionych różnic została potwierdzona $(\mathrm{p}<0,05)$.

\section{DYSKUSJA}

Znaczna część badanych (85\%) wyraża swoje poparcie dla szczepień objętych programem szczepień ochronnych. U pozostałych badanych obawy wynikają przede wszystkim z ogólnodostępnej opinii, iż szczepienie może powodować choroby. Wyniki te są porównywalne z badaniami Kalinowskiego i wsp., w których większość ankietowanych (ok. 65\%) odpowiedziała, że w pewnych warunkach szczepienia mogą zaszkodzić [5]. Rodzice coraz częściej wyrażają negatywne opinie wobec szczepień [12].

Strach przed powikłaniami może skłonić część rodziców do rezygnacji nawet ze szczepień obowiązkowych. Dlatego edukacja społeczeństwa na temat zalet szczepień i możliwych skutków ubocznych jest ważna, gdyż może wyeliminować opinie oparte na piśmiennictwie pseudonaukowym. Pomoże to zredukować strach przed szczepieniami $[13,14]$.

W badaniach na temat szczepień najczęściej pojawiają się pytania o wpływ różnych czynników na kształtowanie opinii w tym temacie. Marchewka i wsp. badały rolę środków masowego komunikowania oraz wpływ poglądów religijnych na postawę wobec szczepień ochronnych. Zauważyły, że rodzice często szukają informacji dotyczących zdrowia swoich dzieci w Internecie, rezygnując tym samym z rozmowy na ten temat z lekarzem rodzinnym. Zgodnie z wynikiem badań prowadzonych przez Polską Bibliotekę Internetową aż $8 \mathrm{mln}$ użytkowników szuka w Internecie informacji na temat problemów zdrowotnych [6]. Traczoń i wsp. wykazali, że 97\% rodziców uważa lekarza za najlepsze źródło informacji na temat szczepień, 75\% - pielęgniarkę, a 48\% - Internet. Połowa z nich sądzi, że wszystkie te źródła są godne zaufania [15]. Również w USA i Szwajcarii badacze wykazali istotny wpływ lekarza na wiedzę i kształtowanie opinii na temat szczepień ochronnych $[16,17]$. W badaniach przeprowadzonych przez Rogalską i wsp. na podobne pytanie odpowiedziano następująco: lekarz - 86\%, media - 66\%, Internet - ok. 20\% [18]. Przytoczone wyniki są porównywalne z rezultatem badań własnych. Zgodnie z nimi 72,5\% uważa lekarza i pielęgniarkę za ważny czynnik kształtowania opinii. Media i Internet są istotne dla $39,5 \%$ badanych. W badaniach własnych istotnego wpływu na opinię respondentów nie miała religia, w tym ksiądz. Jednak w środkach masowego przekazu pojawiają się informacje, że do produkcji szczepionek wykorzystuje się komórki pochodzące z ludzkich płodów. Szczepy wirusów używane w produkcji szczepionek hodowane są na komórkach płuca 3-miesięcznego płodu. Został on pozyskany w wyniku legalnej aborcji przeprowadzonej w 1961 r. w Szwecji. Część społeczeństwa 
uznała szczepienia za niezgodne z podstawami moralnymi i religijnymi [6].

Zgodnie z przeprowadzonymi badaniami własnymi ruch antyszczepionkowy cieszy się poparciem 24,5\% ankietowanych, zaś 75,5\% neguje jego tezy. Pomimo licznych kampanii promujących szczepienia wśród polskich rodziców, np. „Stop pneumokokom”, „Nie! Dla meningokoków”, grono przeciwników ciągle rośnie [19]. Badania wielu autorów wykazały, że antyszczepionkowe publikacje wywołują wśród rodziców wątpliwości, a nawet negatywne nastawienie do szczepień i decyzji o ich realizacji [20, 21, 22].

Część naukowców popiera ruch przeciw szczepieniom i uważa, że obecny w składzie szczepionek tiomersal może powodować autyzm, ADHD oraz inne schorzenia układu nerwowego. Ta teoria nie znalazła jednak poparcia w badaniach naukowych [6]. Pomimo niepokojących doniesień prezentowanych przez przeciwników wakcynologii szczepionka przed dopuszczeniem do użytku musi przejść szereg badań, które wykażą jej skuteczność i pełne bezpieczeństwo [23].

W badaniach Łopaty i wsp. na pytanie „Czy uważa Pan/ Pani, że szczepienia przeciw chorobom zakaźnym wśród dzieci nadal powinny być obowiązkowe?" 80,2\% osób odpowiedziało, że „tak”, natomiast - 19,8\% „nie” [24]. Wynik ten jest porównywalny z pytaniem dotyczącym tego samego aspektu badania własnego. Spośród ankietowanych 84\% uważa, że szczepienia powinny być obowiązkowe, wskazując, że zapobiegają wystąpieniu chorób i stanowią skuteczną profilaktykę. Natomiast $16 \%$ ankietowanych nie zgadza się, by szczepienia były obowiązkowe, co potwierdzają wyniki Veliz i wsp. [25].

\section{WNIOSKI}

Pomimo poparcia dla ruchu antyszczepionkowego większość społeczeństwa uważa obowiązek szczepień za ważny element profilaktyki poważnych chorób. Rodzice twierdzą jednak, że mają ograniczony dostęp do informacji, co uniemożliwia im w pełni świadome podjęcie decyzji o zaszczepieniu dzieci.

\section{PIŚMIENNICTWO}

1. Zaszczep w sobie chęć szczepienia. Państwowa Inspekcja Sanitarna. http:\\ szczepienia.gis.gov.pl (4.11.2016).

2. Beaglehole R, Bonita R. Basic epidemiology. Geneva: WHO; 1993.

3. Gańczak M, Dmytrzyk-Daniłów G, Karakiewicz B, Korzeń M, Szych Z. Determinants influencing self-paid vaccination coverage, in 0-5 years old Polish children. Vaccine 2013;31(48):5687-92. doi: 10.1016/j.vaccine.2013.09.056.
4. Szymczyk H. Szczepienia - najlepsza metoda zwalczania groźnych chorób zakaźnych. Med Ogólna Nauk Zdr 2016;22(4):245-52. doi: 10.5604/20834543.1227604.

5. Kalinowski P, Makara-Studzińska M, Kowalska M. Opinie i poglądy młodych osób dotyczące wykonywania szczepień ochronnych. Hygeia Public Health 2014;49(4):782-6.

6. Marchewka AK, Majewska A, Młynarczyk G. Działalność ruchu antyszczepionkowego, rola środków masowego komunikowania oraz wpływ poglądów religijnych na postawę wobec szczepień ochronnych. Warszawa: Katedra i Zakład Mikrobiologii Lekarskiej WUM; 2014.

7. Moritz A. Szczepienia pełne kłamstw. Szokująca prawda o farmaceutycznych praktykach. Białystok: Vital; 2014.

8. Biss E. O odporności. Szczepić czy nie szczepić dzieci? Warszawa: MT Biznes; 2015.

9. Fernandez S. Aluminum in Vaccines: Addressing Parents' Concerns. Pediatr Ann 2016;45(7):231-3. doi: 10.3928/00904481-20160606-01.

10. Hirte M. Szczepienia. Za \& przeciw. Warszawa: Certa; 2014.

11. Bernatowska E, Mik E, Mrozińska M. Skład i bezpieczeństwo szczepionek. Przew Lek 2004;8:88-101.

12. Reluga TC, Bauch CHT, Galvani AP. Evolving public perceptions and stability in vaccine uptake. Math Biosci 2006;204(2):185-98.

13. Rainey JJ, Watkins M, Ryman TK, Sandhu P, Bo A, Banerjee K. Reasons related to non-vaccination and under-vaccination of children in low and middle income countries: findings from a systematic review of the published literature, 1999-2009. Vaccine 2011;29(46):8215-21. doi: 10.1016/j. vaccine.2011.08.096

14. Kochman D, Rudzińska T. Znaczenie edukacji rodziców w kontekście szczepień obowiązkowych i zalecanych u dzieci w wieku 0-2 lat. Probl Pielęg 2008;16(1-2):163-72.

15. Traczoń I, Domaradzka E, Czajka H. Co na temat szczepień ochronnych wiedzą rodzice i pracownicy ochrony zdrowia? Przegl Lek 2009; 66:1-2.

16. Salmon DA, Moulton LH, Omer SB, deHart MP, Stokley S, Halsey NA. Factors associated with refusal of childhood vaccines among parents of schoolages children. Arch Pediatr Adolesc Med 2005;159(5):470-6. doi: 10.1001/ archpedi.159.5.470.

17. Heininger U. An internet-based survey on parental attitudes towards immunization. Vaccine 2006;24:6351-5. doi: 10.1016/j.vaccine.2006.05.029.

18. Rogalska J, Augustynowicz E, Gzyl A, Steffanoff P. Źródła informacji oraz wiedza rodziców na temat szczepień ochronnych w Polsce. Przegl Epidemiol 2010;64:83-90.

19. Cędrowska B, Olejniczak D. Edukacja zdrowotna kobiet ciężarnych na temat szczepień ochronnych ich dzieci. Nowa Pediatr 2014;2:50-5.

20. Koslap-Petraco M, Parsons T. Communicating the benefits of combination vaccines to parents and health care providers. J Pediatr Health Care 2003;17(2):53-7. https://doi.org/10.1067/mph.2003.42.

21. Szenborn L, Czajka H, Wysocki J. Kontrowersje wokół szczepień. Przegl Lek 2009;66(1-2):65-70.

22. Mastalerz-Migas A, Zagórska J, Steciwko A. Fakty i mity na temat szczepień ochronnych w opinii pacjentów praktyki lekarza rodzinnego. Fam Med Primary Care Rev 2011;13(3):446-9.

23. Kramarz P. Kompleksowe monitorowanie bezpieczeństwa szczepień. Med Prakt Szczep 2012;4(4):15-9.

24. Łopata E, Biesiada P, Kałucka S. Opinie rodziców na temat zasadności szczepień obowiązkowych w Polsce. Fam Med Primary Care Rev 2014;16(3):252-8.

25. Veliz L, Campos C, Vega P. Knowledge and attitudes of the parents in relation to the vaccination of their children. Rev Chilena Infectol 2016;33(1):30-7. doi: 10.4067/S0716-10182016000100005. 